SECTION 21. Pedagogy. Psychology. Innovations in the field of education.

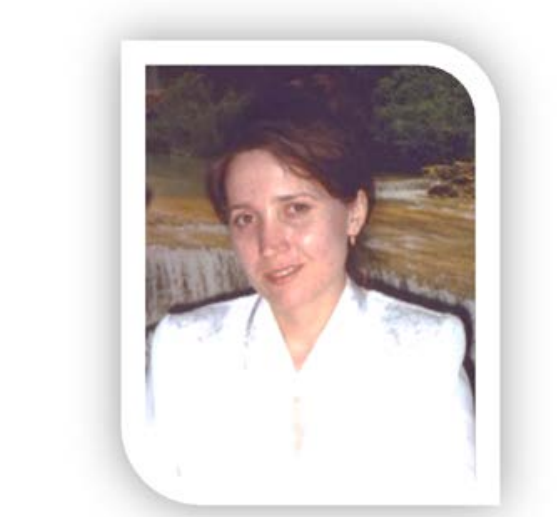

Lyutsiya Rafailyevna Suleymanova secondary school \# 6,

Taraz, Kazakhstan

\title{
METHODS OF FORMATION OF EDUCATIONAL METHODS IN THE STUDY OF THE SPELLING IN THE RUSSIAN LANGUAGE LESSONS
}

\begin{abstract}
The article examines conditions affecting the development process, and the effectiveness of methods of formation of gaming techniques in teaching, and the development of literacy spelling, available for students form showing the advantages of Russian orthography based on morphological principle.

Key words: spelling, game, morphological feature, development, research, sounds, stress, morpheme.

\section{МЕТОДЫ ФОРМИРОВАНИЯ ОБРАЗОВАТЕЛЬНЫХ МЕТОДИК ПРИ ИЗУЧЕНИИ ОРФОГРАФИИ НА УРОКАХ РУССКОГО ЯЗЫКА}

Аннотация: В статье исследуются условия влияющие на процесс развития, а также эффективность методов формирования игровых методик в преподавании, $u$ развитии орфографической грамотности, в доступной для учащихся форме показывая достоинства русской орфографии, основанной на морфологическом принципе.

Ключевые слова: орфография, игра, морфологический признак, развитие, исследование, звуки, ударение, морфемьл.

Русская орфография построена по преимуществу на морфологическом принципе. То есть отдельные написания обозначаются одинаково (независимо от произношения), по аналогии с написаниями, передающими звуки в сильном положении. При этом возникающие звуковые изменения не влекут изменения смысла слов. [1]

Всем учителям известно, что изменение фонем в морфемах [2-3] служат для различения значения слов. Следует, на уроках русского языка, обращать внимание учеников - на дифференцирующую смысловую роль, это внесет в урок оживление, повысит интерес к языку. [4]

При изучении многих правил нужно обращать внимание учащихся на дифференцирующую смысловую роль фонем [3]. Так при изучении фонетики нужно показать смыслоразличительную роль отдельных звуков [5-7], а на письме букв, сопоставляя такие, например, пары слов, как в [8-9] и др.

Например,предложить игру «Потерянная буква». Нужно подобрать к каждой моделе 3-4 слова. Балка-булка-белка, бинт-бант-бунт, мак-лак-бак-рак. Или поиграть в игру «Волшебные цепочки» - Пар преврати в лед. (пар-пир-пик-лик-лак-лад-лед) и т.д. [10-11] 
Использовать слова желательно не слишком трудные, но и не слишком легкие для учеников, в соответствии с их возрастными особенностями. Если слова будут иметь орфографические трудности, то это поможет увязать работу по языку с лексической и орфографической работой. [12]

При знакомстве с ударением можно организовать интересные упражнения в противопоставлении слов, имеющих одинаковое написание, но различающихся в произношении из-за изменения места ударения, познакомить с такими словами в игровой форме: загадать загадки, предложить решить ребусы и др.), например, замок замок, полки-полки, белки - белки. [13]

Когда учащихся знакомят с темой «Твердые и мягкие согласные» [14-15], то здесь широкое поле для сопоставления слов, различающихся твердостью и мягкостью согласных, угольки-уголки, банки-баньки, мел-мель, мол- моль и т.д. можно рещить логические задания, например, преврати словоел в хвойное дерево, слово банька в посуду, слово уголки в сгоревшие дрова. [16]

Такую же работу можно провести и для правописания -й или и в середине и на конце слова: стройте- строите, делайте - делаете, воин- война. [17]

В русском языке имеется несколько слов, различающихся написанием двойной согласной: металл- метал, Ане-Анне, гама- гамма, тон-тонна, вилл- вил, трупа- труппа, балл-бал. Следует показать возможность искажения смысла в случае пропуска двойной согласной или написания лишней, а учащиеся доказывают это, составляя предложения с этими словами, например, Спортсмен ловко метал копье.- Переработанный металл используют на заводах для изготовления различных изделий. [18]

Многие учащиеся начальных классов , особенно национальных классов, не различают шипящие согласные щ и ш, смешивают их при письме. Поэтому целесообразно проводить такие сопоставления, как щей и шей, щит и шит, пищи и пиши, распущу и распушу. При изучении суффиксов чик - щик у имен существительных можно обратить внимание на такие слова как фонарщик и фонарчик [19]

Много слов в русском языке, которые произносятся одинаково, но различаются написанием безударной гласной в корне. Это существительные компания-кампания , чистота-частота. Прилагательные гребной- грибной, глаголы развиваться-развеваться, распевать-распивать, свила-свела, отворить-отварить,. Некоторые из рассматриваемых слов совпадают в своей начальной форме (компания - кампания), другие различаются в начальной форме, но совпадают в других формах (раскалить, но расколоть: раскалю и расколю). Среди интересующих нас слов наряду с вполне понятными для учащихся даже начальных классов(валы - волы) встречаются и менее употребительные, а следовательно, и менее понятные детям (например, компания - кампания, умалю умолю), которые понятны для старших классов. Интересен случай <тройного> совпадения (приводится А.Н Гвоздевым): освещу от осветить: освящу от освятить: освищу от освистать [20]

Для поднятия интереса к русскому языку, при работе с безударными гласными в словах с одинаковым произношением, но разным написанием следует дать занимательные примеры, где ошибочные написания могут привести к искажению смысла, например, заниматься гребным спортом-заниматься грибным спортом.

Упражнения на правописание заглавной буквы в именах собственных особенно интересно построить на материале таких фамилий, для которых имеются созвучные (или отличающиеся только ударением) формы нарицательных имен ( Львов и львов, Ковров и ковров). Поиски таких фамилий, включение их и созвучных нарицательных имен в предложения, несомненно, внесут оживление.

Роль правила правописания сложных слов с дефисом перед гласными (поларбуза, пол-яблока) хорошо иллюстрировать на таких примерах, как пол-ивы, пол-осы, 
пол-овина, пол-очка, где при ошибочном пропуске черточки получаются совсем другие слова (поливы вместо пол-ивы) и т.д.

Знакомя учащихся с окончанием как с такой частью слова, которая изменяется в связи с другими словами, надо обратить их внимание и на то, что с изменением окончания изменяется смысл. Это лучше всего показать на таких, например, сочетаниях, как письмо бабушки (т.е. письмо, написанное бабушкой) и письмо бабушке (т.е. письмо, адресованное бабушке), подарок юноши и подарок юноше и т.д.

Рассматриваемые слова могут быть использованы различно, но всегда главную роль играет их сопоставление.

Еще более убедительной и интересной для учащихся может быть демонстрация таких примеров, где от неправильного написания искажается смысл слова, получается логическая несообразность (мылся в баньке и мылся в банке). Такие примеры особенно хорошо запоминаются учащимся и ярко иллюстрируют вред орфографических ошибок. На двусмысленности рассматриваемых слов или их сочетаний основаны всякого рода загадки, каламбуры, занимательные рассказы, значительная часть которых может быть использована и на уроке. (например, Когда человек может быть деревом? - Когда он со сна: Женщина несла ведро яиц, а дно упало. Сколько осталось?) Для устранения ошибок, состоящих в смешении глаголов на -ться с существительными на -ица (ошибки типа <улится>), интересно сообщить загадку, основанную на совпадении этих слов (Спереди курица, сзади сосуд. Что это такое? Отгадка: сигара). [21]

Дело не в одной только занимательности всех этих загадок и рассказов, не только в этом, что они вносят оживление, а главное в том, что они заинтересовывают учащихся, живо и увлекательно раскрывают значение орфографической грамотности, в доступной для учащихся форме показывают достоинства русской орфографии, основанной на морфологическом принципе. [22-23]

При закреплении правил слова с рассматриваемыми написаниями нужно использовать главным образом для предупредительного или творческого диктанта, для подыскания или записи примеров. Учащимся можно предложить, чтобы они выписали рассматриваемые слова из орфографического словаря.

Возможны, наконец, упражнения словообразовательного типа: от данных слов образовать такие их формы, которые совпадали бы в произношении, например от слов наколоть - накалить - формы накалю - накалю, наколи - накали: или, наоборот, к данным формам подыскать другие их формы, Ясно показывающие различие первых по значению, например, к спиши - спеши подобрать неопределенную форму: списать спешить. [24]

Что касается самостоятельного подбора учащимися рассматриваемых парных слов, то это представляет очень большие трудности и может быть рекомендовано только в старших классах и при условии, если учащимся будут указаны смысловые или грамматические признаки нужных слов. Можно загадать загадку. Придумать два слова: одно - существительное 1 склонения, обозначающее дикое животное, другое существительное 2 склонения во множественном числе, обозначающее, где живет это животное (лиса - леса).

Работа со словами, имеющими написания, различающие их смысл, возможна, как видно, во многих случаях на разных этапах урока и в разнообразных формах. Эта работа повышает у школьников познавательный интерес к русскому языку, их активность.

Исследование проведено под руководством:

- доктора педагогических наук, проф. Папышева А.А., (Казахстан, Астана). 


\section{References:}

1. М.Т. Баранов «Воспитание интереса к урокам русского языка», М-1965, с.6

2. Чередования и внутренняя флексия. [Электронный pecypc] URL: http://www.bibliotekar.ru/yazikovedenie-1/68.htm (Дата доступа 12.04.2014).

3. Фонетический уровень языка. Предмет и задачи фонетики и фонологии как разделов науки о языке. $\mathrm{У}$ ровнем языка [Электронный ресурс] URL: http://ru.convdocs.org/docs/index-108300.html?page=2 (Дата доступа 12.04.2014).

4. Структура дифференциального алгоритма чтения. [Электронный ресурс] URL: http://www.skorost-chtenia.ru/glavy/lesson-3/the-structure-of-differential-readingalgorithm/ (Дата доступа 12.04.2014).

5. Звуки и буквы. [Электронный pecypc] URL: http://nsportal.ru/nachalnayashkola/russkii-yazyk/tema-uroka-zvuki-i-bukvy-smyslorazlichitelnaya-rol-zvukov-ibukv-v (Дата доступа 12.04.2014).

6. Смыслоразличительная роль ударения. [Электронный pecypc] URL: http://festival.1september.ru/articles/570614/ (Дата доступа 12.04.2014).

7. Смыслоразличительная роль звука. [Электронный pecypc] URL: http://cor.edu.27.ru/dlrstore/339d9c16-87f2-4aac-adb9-3f5120ff277c/g2019.htm (Дата доступа 12.04.2014).

8. Метаграммы [Электронный ресурс] URL: http://klavogonki.ru/vocs/194/ (Дата доступа 18.04.2014).

9. Буква на что похожа. [Электронный pecypc] URL: http://www.pandia.ru/text/77/496/661126365.php (Дата доступа 18.04.2014).

10. М.В. Ушаков «Роль сопоставлений в развитии у школьников интереса к работе по орфографии» М-1965, с152

11. Метаграммы, или Можно ли сделать из мухи слона?_[Электронный ресурc] URL: http://olejnikova.ru/2010/08/20/metagrammy-ili-mozhno-li-sdelat-iz-muxi-slona/ (Дата доступа 18.04.2014).

12. Г.П. Шалаева «Большая книга логических игр», М-2011, с.154

13. Садовникова И.Н. Нарушения письменной речи и их преодоление у младших школьников. -M.: Владос, 1997 [Электронный pecypc] URL: http://www.pedlib.ru/Books/1/0317/1_0317-147.shtml (Дата доступа 18.04.2014).

14. Твердые и мягкие согласные. [Электронный ресурс] URL: http://www.razvitierebenka.com/2011/12/blog-post_02.html (Дата доступа 18.04.2014).

15. Согласные звуки и согласные буквы [Электронный pecypc] URL: http://fictionbook.ru/author/elena_ivanovna_litnevskaya/russkiyi_yaziyk_kratkiyi_teoreti cheskiyi_kurs/read_online.html?page=2 (Дата доступа 18.04.2014).

16. Логопедическое занятие по теме "Мягкий знак - показатель мягкости согласных в середине слова" [Электронный pecypc] URL: http://festival.1september.ru/articles/640111/ (Дата доступа 18.04.2014).

17. Правописание гласных и согласных в приставках. [Электронный ресурс] URL: http://www.yaklass.ru/p/russky-yazik/10-klass/orfografiia-10541/pravopisanie-pristavokv-razrabotke-10549/re-b50cbe15-d36b-44aa-a29e-6426ebda04bf (Дата доступа 18.04.2014).

18. В. Волина «Игра- дело серьезное», с87,с.64

19. Буквы "Ч" и "Щ" в суффиксах имен существительных -чик- и -щик. [Электронный pecypc] URL: http://festival.1september.ru/articles/615891/ (Дата доступа 18.04.2014).

20. Анализ слова грибное. [Электронный pecypc] URL: http://www.reright.ru/analysis/850528 грибное.html (Дата доступа 18.04.2014).

21. Правописание "-тся и -ться" в глаголах. [Электронный pecypc] URL: http://festival.1september.ru/articles/628913/ (Дата доступа 18.04.2014). 
22. Николай Владимирович Адамчик. Самый полный курс русского языка / Авт. Н. $\quad$ В. Адамчик. - Минск: Харвест,2008. - 848 с.

23. Орфография. Принципы русской орфография [Электронный ресурс] URL: http://padeji.ru/fonetika/orfografiya-printsipy-russkoi-orfografiya (Дата доступа 18.04.2014).

24. Т. Э. Розенталь «Практическое пособие по русскому языку», М-1990, с.4 